\title{
Meat avoidance: motives, alternative proteins and diet quality in a sample of Swiss consumers
}

\author{
Désirée Hagmann*, Michael Siegrist and Christina Hartmann \\ Department of Health Sciences and Technology, Consumer Behavior, ETH Zurich, Universitätstrasse 22, CH-8092 \\ Zurich, Switzerland
}

Submitted 30 July 2018: Final revision received 14 January 2019: Accepted 4 March 2019: First published online 4 June 2019

\begin{abstract}
Objective: Diets lower in meat are considered both highly beneficial for human health and more environmentally friendly. The present study compared consumer groups with different self-declared diet styles regarding meat (vegetarians/vegans, pescatarians, low- and regular meat consumers) in terms of their motives, protein consumption, diet quality and weight status.

Design: Cross-sectional data from the Swiss Food Panel 2.0 (survey 2017).

Setting: Switzerland, Europe.

Participants: Data of 4213 Swiss adults ( $47.4 \%$ females) from a nationally representative sample living in the German- and French-speaking regions of Switzerland (mean age 55.4 years).

Results: For vegetarians, vegans and pescatarians, ethical concerns about animal welfare and environmental friendliness, as well as taste preferences are stronger reasons to avoid meat consumption. Female low-meat consumers are more likely to be motivated by weight regulation. Only $18 \%$ of the sample and $26 \%$ of selfdeclared low-meat consumers met the official dietary recommendations for meat intake. Concerns about animal welfare and taste preferences predicted lower meat intake, whereas perceived difficulty of practising a low-meat diet and weight-loss motives were associated with higher meat consumption in consumers who reported eating little or no meat.

Conclusions: Our study demonstrates that there can be large discrepancies between consumers' self-perception and their actual meat consumption. This has to be taken into account when designing public health interventions. Addressing ethical concerns about animal welfare (e.g. through awareness campaigns), further improving the range of vegetarian options and increasing consumers' knowledge about the dietary recommendations may be ways to promote diets lower in meat.
\end{abstract}

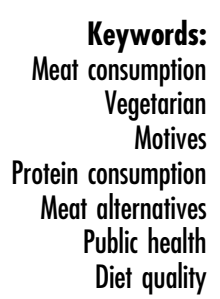

Meat production and consumption have a large impact on human health and the environment ${ }^{(1-4)}$. Evidence from epidemiological studies suggests that opting for more plantbased over meat-based diets would have a positive effect on human longevity and decrease the risk for several modern lifestyle diseases such as diabetes type 2, CVD, obesity and some types of cancer ${ }^{(1,5-7)}$. Additionally, the adoption of such diets would substantially reduce the environmental burden caused by the production of animal proteins ${ }^{(2-4)}$ and the animal suffering caused by many common practices in livestock production ${ }^{(8,9)}$. Increased awareness of the issues associated with meat consumption may be a cause of the increasing popularity of vegan, vegetarian and flexitarian lifestyles ${ }^{(10-12)}$. At the same time, however, global meat consumption is increasing continuously, or in some countries stagnating at a high level of per capita consumption $^{(13,14)}$. Official dietary guidelines such as those of the Swiss Society for Nutrition ${ }^{(15)}$ or the World Cancer Research Fund International ${ }^{(16)}$ strongly recommend moderate consumption of meat, especially of red and processed meat. These guidelines also encourage individuals to frequently replace meat with other sources of animal- and plant-based proteins. Moreover, public organisations are attempting to increase public awareness of the issues associated with high levels of meat consumption ${ }^{(17)}$ in an effort to direct consumer food choices in a more healthy, sustainable direction. The transition to more plant-based diets, however, is challenging ${ }^{(17)}$, especially because meat is very popular and is positively regarded in terms of taste, tradition and beliefs about healthiness by a large portion of 
society $^{(18)}$. According to the Organisation for Economic Cooperation and Development ${ }^{(19)}$, European consumers eat about $70 \mathrm{~kg}$ of meat (i.e. beef/veal, pork, poultry and lamb/mutton; retail weight) per year and thus clearly exceed official recommendations for meat intake ${ }^{(15,16)}$. Because meat consumption can be considered a highly habituated behaviour ${ }^{(20)}$, it is rather difficult for people to change their intake levels. It is thus important to understand what motivates people to consume less or no meat in order to develop strategies that can effectively motivate people who consume excessive amounts of meat to shift their habits towards more plant-based diets.

Previous research has emphasised that the reasons for choosing a vegetarian or semi-vegetarian lifestyle are diverse and vary widely across cultures ${ }^{(21)}$. The most commonly reported reasons for vegetarianism and reduced meat consumption in Western countries are ethical concerns about the rearing and slaughtering of animals for the purpose of meat production, concerns about personal health and the environment, and disgust ${ }^{(18)}$. Other reasons to adopt a diet that excludes some or all types of meat are religious in nature ${ }^{(22)}$, based on attempts to save money ${ }^{(23)}$ or a result of seeking variety beyond the traditional meatbased menu composition ${ }^{(24)}$

Previous research has suggested that vegetarians and non-vegetarians basically have similar motives, but that some motives are mentioned more frequently in one or the other group ${ }^{(18)}$. For vegetarians, the most frequently reported motives are ethical concerns about animal welfare followed by personal health, environmental concerns and disgust towards meat ${ }^{(18)}$. In semi-vegetarians, however, health motives, especially the benefits of a vegetarian diet and the attempt to lose weight by lowering meat intake, are more common ${ }^{(22,24,25)}$ whereas ethical reasons and environmental concerns are less frequently reported in this diet group and thus seem to play a secondary role ${ }^{(18)}$. The motives for following a vegetarian diet may also change over time, because the longer a certain diet style is practised the more knowledge people gain about the diet and related issues $^{(18)}$.

\section{Study aims}

The aim of the present study was threefold. First, it explored differences in motives for low or no meat consumption among vegetarians/vegans, pescatarians and self-declared low-meat consumers. Second, intake levels of both animal- and plant-based proteins were investigated in order to determine whether and with which alternative protein sources low/no-meat consumers may compensate for meat avoidance. The study also compared diet quality and weight status between self-declared diet groups as indicators of the healthiness of more plant-based diets. Third, our study sought to explain which factors predict variance in meat consumption among consumers who reported deliberately eating little or no meat. More specifically, it investigated which motives are linked to lower meat consumption and whether the consumption of plant-based alternatives is associated with lower meat intake.

A large sample of Swiss adults from different sociodemographic groups was used to achieve a high level of generalisability. The results of the study are relevant for public health organisations' efforts to support people to keep their meat consumption within a healthy range.

\section{Methods}

\section{Participants}

The present study used data from the Swiss Food Panel 2.0, a longitudinal study of the eating behaviours of the Swiss population. The first wave of data was collected during the spring of 2017. The survey consisted of a paper-andpencil questionnaire which was sent to a random sample of residents in the German- and French-speaking regions of Switzerland. Additional addresses from people aged between 20 and 30 years were purchased from an address company to ensure the presence of a sufficient proportion of younger adults in the sample. The questionnaires were completed and returned by 5781 people, representing a response rate of $25 \cdot 1 \%$. Participants who did not indicate their gender or age and those who completed less than $50 \%$ of the questionnaire were excluded ( $n$ 195). Women who were pregnant at the time ( $n$ 348) were also excluded, because analyses including BMI were conducted. After these exclusions, 5238 participants remained in the final sample. Of these, $48.7 \%$ were females and $73.8 \%$ were German speakers. The mean age of the sample was 56.5 (SD 17.3) years (range $=20-100$ years). Compared with the census $(33.4 \%)$, young adults $20-39$ years old were under-represented (17\%). For the present analysis, only participants with no missing answers to questions on the relevant variables (diet style and meat reduction) were considered ( $n$ 4213; $47.4 \%$ females; mean age $=55.4$ years).

\section{Individual measures}

\section{Motives for low or no meat consumption}

First, participants were asked a filter question, 'Do you intentionally eat little or no meat?' Participants who answered 'yes' were then asked about the strength of a variety of motives for low or no meat consumption. Motives were assessed with twelve statements and a Likert-type response scale (e.g. 'I eat little or no meat because I want to eat healthily'; see Table 1). Response options ranged from 1 ('totally disagree') to 7 ('totally agree').

\section{Perceived difficulty of low or no meat consumption}

The perceived difficulty of practising a diet containing little or no meat was assessed with one item: 'How difficult is it 
Table 1 Items assessing motives for no or low meat consumption

Motive

Motive category

Cronbach's $\alpha$

'I eat little or no meat because ...'

1. '... it helps me regulate my weight' $\dagger$

2. '... I want to eat healthily'

3. ‘... I frequently don't like the taste' $\dagger$

4. '... I prefer the taste of vegetarian dishes' $\dagger$

5. ' $\ldots$ it is better for the environment' $\dagger$

6. ' '... I want to eat in an environmentally friendly way'

7. ' '... meat production has negative effects on animal welfare'

8. '... I consider it unethical that animals are killed to produce meat'

9. ' '... my doctor recommended it to me'

10. '... my religion forbids me to eat (certain types of) meat' $\dagger$

11. '... I was brought up that way'

12. ' ... my social environment expects it from me'

†ltem was adapted from De Backer and Hudders ${ }^{(22)}$.

for you to practise a diet with little or no meat?'. The response scale varied from 1 ('not at all difficult') to 7 ('very difficult').

\section{Diet style}

Participants were asked to indicate whether they defined themselves as omnivore (a typical Western diet including meat and other animal-based foods), pescatarian (no meat but fish and seafood), vegetarian (no meat, fish or seafood, but other animal-based foods such as dairy products or eggs) or vegan (no animal-based foods). Diet styles were predefined in the questionnaire according to the definitions presented in parentheses above. Based on that self-declaration and independent of their self-reported dietary behaviour as measured with an FFQ (see next section), participants were classified into the different diet styles. Of all the participants in the sample, $82.5 \%$ ( $n$ 4321) indicated their diet style. Of those participants, $93.0 \%$ ( $n$ 4019) were self-defined omnivores, $2.9 \%$ ( $n$ 127) pescatarians, $3.6 \%$ ( $n$ 156) vegetarians and $0.4 \%$ ( $n$ 19) vegans. Due to the small group size of vegans, vegans and vegetarians were collapsed into one group ( $n$ 175). In addition, omnivores were split into two groups based on the filter question presented above ('Do you intentionally eat little or no meat?'). Those who indicated that they deliberately ate little meat were labelled as (subjective) lowmeat consumers ( $n$ 1296) and those who did not as (subjective) regular meat consumers ( $n$ 2615). All participants who failed to respond to any of the questions about diet style or meat consumption were excluded from the analyses, because they could not be clearly classified.

\section{Self-reported food consumption}

The survey included a semi-quantitative FFQ (sFFQ) which consisted of a subset of food items and nine response options adapted from the Nurses' Health Study questionnaire ${ }^{(26)}$. Typical consumption frequencies of forty-seven types of food and beverage during the past year were assessed. As in the original questionnaire ${ }^{(26)}$, for each item a standard portion was specified (e.g. '100-120 g of beef/ veal' or 'one handful or $120 \mathrm{~g}$ of fruit'), and the participants were asked to indicate the amount of standard portions they usually consumed. For the analysis, the number of portions per week was calculated by recoding the response options as follows: ' 4 or more per day' $(=28$ portions/ week), '3 per day' (=21), '2 per day' $(=14)$, ' 1 per day' $(=7)$, '5-6 per week' $(=5.5)$, '2-4 per week' $(=3)$, '1 per week' $(=1)$, ' $1-3$ per month' $(=0.5)$ and 'seldom/ never' ( $=0$ portions/week). Consumption frequencies of four types of unprocessed meat (including pork, beef/veal, poultry, and other types of meat such as venison and lamb) and two types of processed meat (including sausages and cold cuts such as salami or bacon) were assessed. The predefined portion of unprocessed meat was 100-120 g; for processed meat it was three slices for cold cuts and one piece for sausages. Total meat consumption was calculated by summing up the weekly portions of all six meat items. A plausibility check of the calculated total meat consumption revealed implausibly high total amounts of meat consumed per week for some participants. Therefore, an upper limit of 35 portions/week ( 5 portions/d) was defined, and all values above this limit were corrected down and set to 35 portions/week. The sFFQ also asked for information regarding the consumption frequency of other animal-based proteins, including fish and seafood, eggs and dairy products ((cow's) milk, quark, cheese, yoghurt and cottage cheese), as well as of plant-based proteins including meat substitutes such as tofu and vegetarian cold cuts, legumes and soya products (soya milk and soya yoghurt). The pre-specified portion size was 100-120 g for fish and seafood; one egg; one glass or $200 \mathrm{ml}$ for cow's and soya milk; 150-200 g or one bowl for quark, yoghurt and cottage cheese; 30-60 g for cheese; and $200 \mathrm{ml}$ or one cup for (cooked) legumes.

\section{Diet quality index}

As an indicator of the healthiness of the participants' diet, a diet quality index was calculated based on the self-reported consumption frequencies of the following five food/beverage groups: (i) fruit (excluding fruit juice); (ii) vegetables and salad (raw and cooked); (iii) wholegrain products (bread, rice, and pasta); (iv) meat and meat products; and (v) sweets, salty snacks, sugar-sweetened beverages and alcohol. These foods and beverages were selected based on official dietary 
guidelines $^{(15)}$ and because previous studies have shown that their consumption either positively or negatively affects health $^{(27)}$. For each food group, the recommended minimum or maximum amount of weekly intake was used as the cut-off value (see Appendix 1). For foods with a positive impact on health (fruit, vegetables and salad, wholegrain products), one point was assigned if a participant's consumption was equal to or higher than the recommended minimum. For all other indicators, one point was assigned if consumption was equal to or below the recommended maximum. A summary score for these points was calculated to create the diet quality index. Possible scores ranged from 0 (rather unhealthy diet) to 5 (rather healthy diet). Research has shown that diet quality indices based on dietary recommendations are valid measures with good predictive power for morbidity and all-cause mortality when combined with other risk factors such as age, gender, smoking or $\mathrm{BMI}^{(28,29)}$.

\section{Weight status}

BMI was calculated as the quotient of self-reported body weight (in kilograms) divided by the square of height (in metres). Participants with a BMI $\geq 25.0 \mathrm{~kg} / \mathrm{m}^{2}$ were categorised as overweight. In the present sample, the mean BMI of the participants was 25.9 (SD 4.00 ) kg/m² for males and $23.7(\mathrm{SD} 4.42) \mathrm{kg} / \mathrm{m}^{2}$ for females. More males in the sample $(54.9 \% v .50 \%$ in the census) and fewer females (28.3\% v. $32 \%$ in the census) were overweight than in the general Swiss population ${ }^{(30)}$.

\section{Sociodemographic characteristics}

The questionnaire included questions about the participants' gender, age, monthly net household income in Swiss francs and education, among other sociodemographic variables. Six response options were used for household income, ranging from 'less than 3000 Swiss francs' to 'more than 11000 Swiss francs'.

\section{Data analysis}

The statistical analyses were conducted using the statistical software package IBM SPSS Statistics version 25. One-way ANOVA using the Games-Howell post hoc test were conducted to compare the groups with the diverse diet styles. This post hoc test is adequate for comparing groups of very different group sizes and if the homogeneity of variances is not given ${ }^{(31)}$. For categorical variables, $\chi^{2}$ tests were calculated. $t$ Tests for independent samples were used to compare men and women with respect to several variables. A principal component analysis with varimax rotation was used to analyse whether some of the assessed motives for low/no meat consumption could be combined into one component. Finally, a three-step hierarchical regression analysis based on 1000 bootstrapped samples was used to identify predictors of total meat consumption among those participants who reported deliberately eating little or no meat (bootstrapping was used to deal with outliers). Sociodemographic characteristics (step 1), motives (step 2), the perceived difficulty of practising a diet with little or no meat consumption and the consumption of plant-based proteins (step 3) were included in the regression model as predictors. Due to the large sample size, only $P$ values below 0.01 were considered significant in all statistical tests.

\section{Results}

The proportion of females in the four diet styles differed substantially, $\chi^{2}=263.31, P<0.001$ (vegetarians/vegans $=$ $76.6 \%$, pescatarians $=71.7 \%$, subjective low-meat consumers $=60.0 \%$, regular meat consumers $=38.0 \%$ ). Therefore, all group comparisons were conducted separately for males and females. The groups did not differ significantly in age with the exception of the vegetarians/ vegans, who were significantly younger (mean 49.22 (SD 17.87) years) than the pescatarians (mean 55.83 (SD 16.34) years), the low-meat consumers (mean 56.28 (SD 15.99) years) and the regular meat consumers (mean $55 \cdot 30$ (sD 16.87) years).

\section{Motives for consuming little or no meat}

Table 1 shows the items used to assess the participants' motives for following a diet with low or no meat consumption. Based on the results of the principal component analysis (scree plot, eigenvalue $>1$, content-based considerations), two items were combined in each case for the motive categories of taste, environmental concerns and animal welfare. Table 1 shows the Cronbach's $\alpha$ for those items which were combined into one motive category. Mean values for the motives separated by diet style (i.e. vegetarian/vegan, pescatarian, low-meat consumer) and gender are graphically displayed in Fig. 1. The regular meat consumers were not included in this comparison, because it would have been nonsensical to ask them to indicate their motivation for meat avoidance. One-way independent ANOVA revealed significant differences in the motivation for low or no meat consumption between the three diet styles. In particular, environmental and animal welfare concerns were highly endorsed by vegetarians/vegans and pescatarians, but less so by low-meat consumers. Taste-related motives were a stronger motivation for low/no meat consumption for vegetarians/vegans and pescatarians than for low-meat consumers. Health motives did not differ between the diet styles. Lastly, low-meat consumers (females only) were more strongly motivated by weight-related motives than were vegetarians/vegans and pescatarians. There were no differences between diet styles observed in the other motives assessed. In particular, no differences were observed for the motives related to medical advice, religious rules, upbringing or social expectations. Subjective low-meat consumers considered it more difficult to maintain a low level of meat consumption compared with vegetarians/vegans but not compared with pescatarians (see Table 4). There was also 

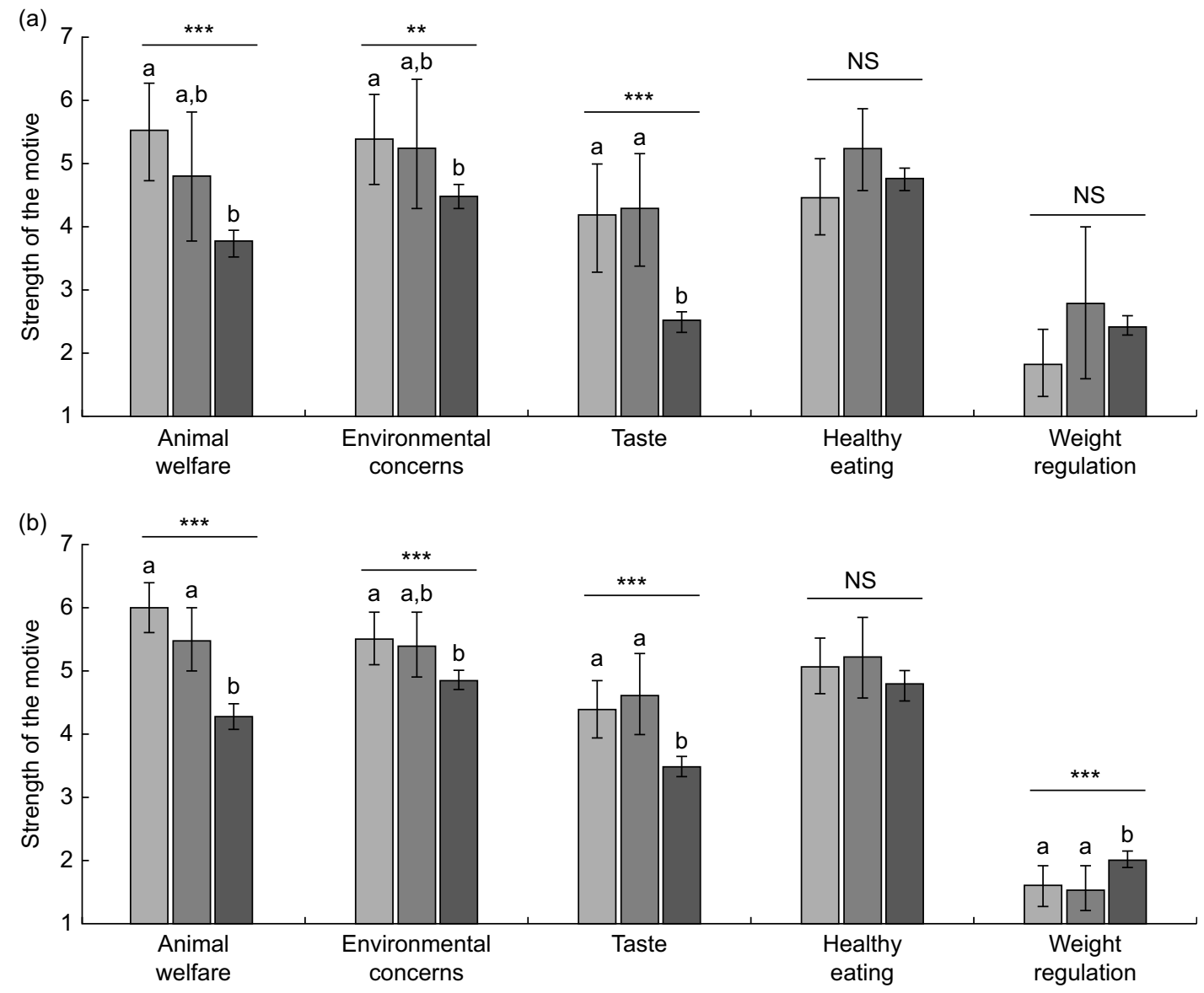

Fig. 1 Motives for vegetarianism and low meat consumption in different diet styles $(\square$, vegetarians/vegans (males, $n 41$; females, $n$ 134); $\square$, pescatarians (males, $n$ 36; females, $n$ 91); $\square$, low-meat consumers (males, $n$ 519; females, $n$ 777)), according to gender (a, males; b, females), in a sample of Swiss adults ( $n$ 1598); Swiss Food Panel 2.0 (survey 2017). The two aspects of taste motives (i.e. not liking the taste of meat and preferring vegetarian foods) were analysed together here because the results for both aspects were the same; $n$ per group varies due to missing values. Values are means with their $99 \% \mathrm{Cl}$ represented by vertical bars. One-way independent ANOVA were used to investigate differences in motives between diet styles. ${ }^{\mathrm{a}, \mathrm{b}}$ Mean values with unlike superscript letters were significantly different according to the Games-Howell post hoc test $(P \leq 0.01) .{ }^{* \star} P<0.01,{ }^{\star \star \star} P \leq 0.001$

a gender difference: males reported more difficulties than females with practising a low-meat or meatless diet.

\section{Dietary behaviour, diet quality and weight status}

Tables 2 (males) and 3 (females) show the mean consumption frequencies of different protein sources for each diet style. In males, consumption of processed, unprocessed and thus total meat did not differ between vegetarians/ vegans, pescatarians and self-declared low-meat consumers. In females, however, the lowest consumption of processed, unprocessed and total meat was in fact reported by vegetarians/vegans. Among all diet style groups, the highest consumption of fish was reported by male and female pescatarians. The weekly intake of eggs and dairy products did not differ between any of the groups in either males or females. Male vegetarians reported a considerably higher total meat intake (Table 3) than did vegetarian females (Table 2).

With regard to meat substitutes, male and female vegetarians/vegans and pescatarians reported the highest consumption. Self-declared low-meat consumers also ate more of these foods than self-declared regular meat consumers. For the males, consumption frequency of other plant-based proteins did not differ among the groups. For females, the differences were more pronounced: vegetarians and vegans consumed more of all kinds of plant proteins than did the two meat consumer groups (regular and low).

For both genders, the regular meat consumers had the lowest diet quality of all groups, followed by the self-declared low-meat consumers (Table 4). Further, the percentage of overweight people (i.e. $\mathrm{BMI}=25 \cdot 0$ $29.99 \mathrm{~kg} / \mathrm{m}^{2}$ ), and in females the percentage of obese people (i.e. $\mathrm{BMI} \geq 30 \cdot 0 \mathrm{~kg} / \mathrm{m}^{2}$ ), was considerably 
Table 2 Consumption of animal-and plant-based proteins (weekly portions) by a sample of Swiss adult males ( $n$ 2216); Swiss Food Panel 2.0 (survey 2017)

\begin{tabular}{|c|c|c|c|c|c|c|c|c|c|}
\hline \multirow[b]{3}{*}{ Protein source } & \multicolumn{8}{|c|}{ Diet style } & \multirow[b]{3}{*}{$F_{(\mathrm{df1}, \mathrm{df} 2)}$} \\
\hline & \multicolumn{2}{|c|}{$\begin{array}{c}\text { Vegetarians } \\
\text { \& vegans } \\
(n \text { 41) }\end{array}$} & \multicolumn{2}{|c|}{$\begin{array}{c}\text { Pescatarians } \\
(n 36)\end{array}$} & \multicolumn{2}{|c|}{$\begin{array}{l}\text { Self-declared } \\
\text { low-meat } \\
\text { consumers } \\
(n 519)\end{array}$} & \multicolumn{2}{|c|}{$\begin{array}{l}\text { Self-declared } \\
\text { regular meat } \\
\text { consumers } \\
(n 1620)\end{array}$} & \\
\hline & Mean & SD & Mean & SD & Mean & SD & Mean & SD & \\
\hline \multicolumn{10}{|l|}{ Animal-based } \\
\hline Unprocessed meat† & $2 \cdot 02^{\mathrm{a}}$ & $5 \cdot 14$ & $3.39^{a}$ & 4.56 & $3.99^{a}$ & $2 \cdot 78$ & $6 \cdot 37^{b}$ & 5.35 & $F_{(3,2186)}=23 \cdot 58^{\star * *}$ \\
\hline Processed meat (sausages, cold cuts) & $1.56^{a}$ & $4 \cdot 11$ & $2 \cdot 94^{a, b, c}$ & 6.56 & $2 \cdot 45^{a, b}$ & $2 \cdot 58$ & $4.25^{\mathrm{c}}$ & 4.58 & $F_{(3,2190)}=27 \cdot 71^{\star * *}$ \\
\hline Total meatł & $3 \cdot 24^{\mathrm{a}}$ & 6.79 & $4 \cdot 69^{a}$ & 5.03 & $6 \cdot 42^{\mathrm{a}}$ & $4 \cdot 17$ & $10 \cdot 23^{b}$ & $5 \cdot 81$ & $F_{(3,2175)}=85 \cdot 48^{\star \star \star}$ \\
\hline Fish and seafood & $0.45^{\mathrm{a}}$ & 1.20 & $1.58^{b}$ & 1.60 & $0.89^{a}$ & 1.02 & $0.89^{\mathrm{a}}$ & 1.32 & $F_{(3,2199)}=4 \cdot 96^{\star *}$ \\
\hline Eggs & 2.07 & $2 \cdot 11$ & 2.08 & $2 \cdot 84$ & $2 \cdot 00$ & $2 \cdot 22$ & 2.00 & $2 \cdot 43$ & $F_{(3,2195)}=0.02^{\mathrm{NS}}$ \\
\hline Dairy products & 12.43 & 9.54 & 11.43 & $6 \cdot 18$ & 13.24 & $8 \cdot 19$ & $12 \cdot 71$ & 9.56 & $F_{(3,2170)}=0.71^{\mathrm{NS}}$ \\
\hline \multicolumn{10}{|l|}{ Plant-based } \\
\hline Meat substitutes (e.g. tofu, Quorn, seitan) & $1.67^{\mathrm{a}}$ & 1.87 & $0 \cdot 87^{a, b, c}$ & 1.90 & $0.26^{b}$ & 0.64 & $0.13^{c}$ & 0.98 & $F_{(3,2197)}=41 \cdot 92^{\star \star \star}$ \\
\hline Vegetarian cold cuts & $0.59^{a}$ & 1.36 & $0 \cdot 13^{a}$ & 0.54 & $0.05^{a}$ & 0.32 & $0.05^{a}$ & 0.77 & $F_{(3,2188)}=7 \cdot 69^{\star \star \star}$ \\
\hline Soya products (milk, yoghurt) & $1.55^{a}$ & 3.45 & $0.55^{a}$ & 2.09 & $0.29^{a}$ & 1.42 & $0.12^{a}$ & $1 \cdot 38$ & $F_{(3,2182)}=14 \cdot 30^{* * *}$ \\
\hline Legumes (e.g. lentils, peas, beans) & $3 \cdot 85^{a}$ & $5 \cdot 30$ & $2 \cdot 13^{a}$ & 2.94 & $1.92^{\mathrm{a}}$ & $2 \cdot 32$ & $1 \cdot 71^{\mathrm{a}}$ & $2 \cdot 49$ & $F_{(3,2194)}=10 \cdot 22^{\star * *}$ \\
\hline
\end{tabular}

$n$ per group varies due to missing values.

One-way ANOVA were used to investigate differences in the consumption of protein sources between diet styles.

a,b,c Mean values within a row with unlike superscript letters were significantly different according to the Games-Howell post hoc test $(P \leq 0.01)$.

${ }^{\star \star} P<0.01,{ }^{\star \star \star} P \leq 0.001$.

†Including beef, pork, poultry and other types of meat such as venison or lamb.

$\ddagger$ Total meat consumption differs slightly from the sum of the single meat items, because implausible extreme values in this variable were corrected and set to a maximum of 35 portions/week; this number also includes other types of meat (e.g. lamb, venison).

Table 3 Consumption of animal- and plant-based proteins (weekly portions) by a sample of Swiss adult females ( $n$ 1997); Swiss Food Panel 2.0 (survey 2017)

\begin{tabular}{|c|c|c|c|c|c|c|c|c|c|}
\hline \multirow[b]{3}{*}{ Protein source } & \multicolumn{8}{|c|}{ Diet style } & \multirow[b]{3}{*}{$F_{(\mathrm{df1}, \mathrm{df} 2)}$} \\
\hline & \multicolumn{2}{|c|}{$\begin{array}{c}\text { Vegetarians } \\
\text { \& vegans } \\
(n 134)\end{array}$} & \multicolumn{2}{|c|}{$\begin{array}{c}\text { Pescatarians } \\
(n 91)\end{array}$} & \multicolumn{2}{|c|}{$\begin{array}{c}\text { Self-declared } \\
\text { low-meat } \\
\text { consumers } \\
(n 777) \\
\end{array}$} & \multicolumn{2}{|c|}{$\begin{array}{c}\text { Self-declared } \\
\text { regular meat } \\
\text { consumers } \\
(n \text { 995) }\end{array}$} & \\
\hline & Mean & SD & Mean & SD & Mean & SD & Mean & SD & \\
\hline \multicolumn{10}{|l|}{ Animal-based } \\
\hline Unprocessed meat $†$ & $0.32^{\mathrm{a}}$ & 0.71 & $2.09^{b}$ & 5.09 & $3 \cdot 41^{c}$ & $2 \cdot 27$ & $5 \cdot 49^{d}$ & 3.52 & $F_{(3.1959)}=159 \cdot 11^{* \star *}$ \\
\hline Processed meat (sausages, cold cuts) & $0 \cdot 14^{a}$ & 0.46 & $0.54^{a}$ & $1 \cdot 21$ & $1 \cdot 88^{b}$ & 1.98 & $2.95^{c}$ & $2 \cdot 67$ & $F_{(3,1978)}=93 \cdot 39^{\star * *}$ \\
\hline Total meatł & $0.46^{a}$ & 1.07 & $2.53^{\mathrm{b}}$ & 4.82 & $5 \cdot 28^{\mathrm{c}}$ & 3.35 & $8 \cdot 41^{d}$ & 4.68 & $F_{(3,1956)}=221.99^{\star \star \star}$ \\
\hline Fish and seafood & $0.17^{a}$ & 0.37 & $1.43^{\mathrm{c}}$ & 1.54 & $0.83^{b}$ & 1.03 & $0.87^{b}$ & 1.30 & $F_{(3,1971)}=22 \cdot 25^{\star \star *}$ \\
\hline Eggs & $2 \cdot 16$ & $2 \cdot 73$ & $2 \cdot 26$ & $2 \cdot 01$ & $2 \cdot 14$ & $2 \cdot 14$ & 2.01 & 2.05 & $F_{(3,1967)}=0.81^{\mathrm{NS}}$ \\
\hline Dairy products & $11 \cdot 18$ & $10 \cdot 43$ & 12.58 & 9.64 & $13 \cdot 17$ & $8 \cdot 13$ & $12 \cdot 45$ & 7.52 & $F_{(31952)}=2 \cdot 71^{\mathrm{NS}}$ \\
\hline \multicolumn{10}{|l|}{ Plant-based } \\
\hline Meat substitutes (e.g. tofu, Quorn, seitan) & $1 \cdot 75^{a}$ & $2 \cdot 17$ & $1.09^{a}$ & 1.44 & $0.37^{b}$ & 0.75 & $0.12^{c}$ & 0.39 & $F_{(3,1975)}=171 \cdot 16^{\star \star \star}$ \\
\hline Vegetarian cold cuts & $0.51^{a}$ & 1.36 & $0.25^{a, b}$ & 0.77 & $0.03^{b}$ & 0.20 & $0.03^{b}$ & 0.26 & $F_{(3,1965)}=52 \cdot 49^{\star \star *}$ \\
\hline Soya products (milk, yoghurt) & $1.47^{a}$ & 3.23 & $1.05^{a, b}$ & $2 \cdot 25$ & $0.49^{b, c}$ & 1.91 & $0 \cdot 26^{c}$ & 1.56 & $F_{(3,1966)}=19 \cdot 18^{\star * *}$ \\
\hline Legumes (e.g. lentils, peas, beans) & $3 \cdot 15^{\mathrm{a}}$ & $4 \cdot 30$ & $2 \cdot 86^{a, b}$ & 4.09 & $1.59^{b, c}$ & 2.06 & $1.39^{c}$ & 2.06 & $F_{(3,1972)}=28 \cdot 70^{\star \star}$ \\
\hline
\end{tabular}

$n$ per group varies due to missing variables.

One-way ANOVA were used to investigate differences in the consumption of protein sources between diet styles.

$\mathrm{a}, \mathrm{b}, \mathrm{c}, \mathrm{d}$ Mean values within a row with unlike superscript letters were significantly different according to the Games-Howell post hoc test $(P \leq 0.01)$.

${ }^{\star *} P<0.01,{ }^{* *} P \leq 0.001$.

†Including beef, pork, poultry and other types of meat such as venison or lamb.

$\ddagger$ Total meat consumption differs slightly from the sum of the single meat items, because implausible extreme values in this variable were corrected and set to a maximum of 35 portions/week; this number also includes other types of meat (e.g. lamb, venison). 
Table 4 Perceived difficulty of low or no meat intake, diet quality and weight, according to self-reported diet styles and gender, of a sample of Swiss adults; Swiss Food Panel 2.0 (survey 2017)

\begin{tabular}{|c|c|c|c|c|c|c|c|c|c|}
\hline & \multicolumn{2}{|c|}{$\begin{array}{l}\text { Vegetarians } \\
\text { \& vegans }\end{array}$} & \multicolumn{2}{|c|}{ Pescatarians } & \multicolumn{2}{|c|}{$\begin{array}{c}\text { Self-declared } \\
\text { low-meat } \\
\text { consumers }\end{array}$} & \multicolumn{2}{|c|}{$\begin{array}{c}\text { Self-declared } \\
\text { regular meat } \\
\text { consumers }\end{array}$} & \multirow[b]{2}{*}{$F_{(\mathrm{df1}, \mathrm{df} 2)}$ or $\chi_{(\mathrm{df})}^{2}$} \\
\hline & $\begin{array}{l}\text { Mean } \\
\text { or } \% \\
\end{array}$ & SD & $\begin{array}{l}\text { Mean } \\
\text { or } \%\end{array}$ & SD & $\begin{array}{l}\text { Mean } \\
\text { or } \%\end{array}$ & SD & $\begin{array}{l}\text { Mean } \\
\text { or \% }\end{array}$ & SD & \\
\hline Males & $n 41$ & & $n 36$ & & $n 519$ & & n 1620 & & \\
\hline Age (years) & $54 \cdot 1$ & $17 \cdot 7$ & 64.6 & $14 \cdot 3$ & $59 \cdot 6$ & $16 \cdot 1$ & $58 \cdot 2$ & $16 \cdot 1$ & $F_{(3,2212)}=3.67$ \\
\hline Diet quality† & $2 \cdot 84^{\mathrm{a}}$ & $1 \cdot 10$ & $2 \cdot 32^{\mathrm{a}, \mathrm{b}}$ & $1 \cdot 16$ & $1 \cdot 73^{b}$ & 1.03 & $1 \cdot 26^{\mathrm{C}}$ & $0 \cdot 85$ & $F_{(3,2046)}=74 \cdot 80^{* * *}$ \\
\hline $\begin{array}{l}\% \text { Meeting the dietary recommendations for } \\
\text { meat intake } \neq\end{array}$ & $79 \cdot 2$ & - & $54 \cdot 8$ & - & $19 \cdot 5$ & - & $3 \cdot 6$ & - & $\chi_{(3)}^{2}=462 \cdot 86^{\star * *}$ \\
\hline Perceived difficulty & $1 \cdot 39^{a}$ & 0.79 & $2 \cdot 19^{a, b}$ & $1 \cdot 73$ & $2 \cdot 47^{b}$ & 1.51 & - & - & $F_{(2,567)}=9 \cdot 63^{\star \star \star}$ \\
\hline BMI $\left(\mathrm{kg} / \mathrm{m}^{2}\right)$ & $25 \cdot 1^{\mathrm{a}, \mathrm{b}}$ & $4 \cdot 1$ & $25 \cdot 9^{a, b}$ & $4 \cdot 3$ & $24 \cdot 9^{\mathrm{a}}$ & $3 \cdot 4$ & $26 \cdot 1^{\mathrm{b}}$ & 3.9 & $F_{(3,2191)}=12 \cdot 73^{\star \star *}$ \\
\hline$\%$ Overweight $\left(\mathrm{BMI}=25 \cdot 0-29.99 \mathrm{~kg} / \mathrm{m}^{2}\right)$ & $30 \cdot 0$ & - & $20 \cdot 0$ & - & $36 \cdot 6$ & - & $44 \cdot 0$ & - & $\chi_{(3)}^{2}=17 \cdot 84^{\star \star \star}$ \\
\hline$\%$ Obese $\left(\mathrm{BMI} \geq 30.0 \mathrm{~kg} / \mathrm{m}^{2}\right)$ & $12 \cdot 5$ & - & $22 \cdot 9$ & - & $5 \cdot 8$ & - & $12 \cdot 8$ & - & $\chi_{(3)}^{2}=23.73^{\star \star \star}$ \\
\hline Females & $n 134$ & & $n 91$ & & $n 777$ & & $n 995$ & & \\
\hline Age (years) & $47 \cdot 7^{\mathrm{a}}$ & $17 \cdot 7$ & $52 \cdot 4^{a, b}$ & $15 \cdot 8$ & $54 \cdot 1^{b}$ & $15 \cdot 5$ & $50 \cdot 6^{c}$ & $17 \cdot 0$ & $F_{(3,1993)}=9 \cdot 60^{\star \star \star}$ \\
\hline Diet quality $†$ & $3.49^{a}$ & $1 \cdot 11$ & $3 \cdot 22^{\mathrm{a}}$ & $1 \cdot 20$ & $2 \cdot 33^{b}$ & $1 \cdot 12$ & $1 \cdot 77^{\mathrm{C}}$ & 1.05 & $F_{(3,1831)}=133 \cdot 31^{\star * \star}$ \\
\hline $\begin{array}{l}\% \text { Meeting the dietary recommendations for } \\
\text { meat intakef }\end{array}$ & $96 \cdot 9$ & - & $78 \cdot 7$ & - & $30 \cdot 8$ & - & $7 \cdot 0$ & - & $\chi_{(3)}^{2}=728 \cdot 03^{\star \star \star}$ \\
\hline Perceived difficulty§ & $1.36^{\mathrm{a}}$ & 0.96 & $1 \cdot 73^{a, b}$ & $1 \cdot 39$ & $2 \cdot 02^{\mathrm{b}}$ & $1 \cdot 28$ & - & - & $F_{(2,971)}=16 \cdot 87^{\star \star \star}$ \\
\hline BMI $\left(\mathrm{kg} / \mathrm{m}^{2}\right)$ & $21 \cdot 7^{a}$ & $2 \cdot 9$ & $22 \cdot 1^{\mathrm{a}}$ & $3 \cdot 3$ & $23 \cdot 4^{b}$ & $4 \cdot 1$ & $24 \cdot 2^{c}$ & $4 \cdot 7$ & $F_{(3,1965)}=19 \cdot 68^{\star \star \star}$ \\
\hline$\%$ Overweight $\left(\mathrm{BMI}=25 \cdot 0-29.99 \mathrm{~kg} / \mathrm{m}^{2}\right)$ & $10 \cdot 8$ & - & 14.4 & - & $17 \cdot 8$ & - & $20 \cdot 9$ & - & $\chi_{(3)}^{2}=10.09^{*}$ \\
\hline$\%$ Obese $\left(\mathrm{BMI} \geq 30 \cdot 0 \mathrm{~kg} / \mathrm{m}^{2}\right)$ & $2 \cdot 3$ & - & $2 \cdot 2$ & - & $6 \cdot 9$ & - & $10 \cdot 9$ & - & $\chi_{(3)}^{2}=20 \cdot 76^{\star * *}$ \\
\hline
\end{tabular}

$n$ per group varies due to missing values.

One-way ANOVA and $\chi^{2}$ tests were used to investigate differences between the groups.

a,b,c Mean values within rows with unlike superscript letters were significantly different according to the Games-Howell post hoc test $(P \leq 0.01)$

${ }^{* \star} P<0.01,{ }^{* * \star} P \leq 0.001$.

†Diet quality index based on recommendations of the Swiss Society for Nutrition ${ }^{(15)}$.

†Percentage of individuals per group who did not eat more than the maximum recommended amount of three portions of meat per week (Swiss Society for Nutrition ${ }^{(15)}$ ). Based on self-reported meat consumption on the FFQ.

§Perceived difficulty of practising a diet with little or no meat.

higher among self-declared regular and low-meat consumers than in the other groups (Table 4). However, in males the prevalence of obesity was highest in the pescatarian group.

\section{Adberence to dietary recommendations for meat intake}

A relatively high percentage of individuals (82.0\%) exceeded the weekly recommended maximum of three portions of meat and meat products. This percentage was higher among males (90.3\%) than females (73.1\%). Only $4.5 \%$ of the sample indicated never eating meat or meat products in the sFFQ, and $55.7 \%$ reported eating one portion of meat or even more per day. The percentage of participants in the sample that met the official dietary recommendation for meat intake separated by diet style is shown in Table 4. Among self-declared low-meat consumers, the percentage of participants whose meat consumption fell within the recommended amount was rather low (19.5\% in men, 30.8\% in women).

\section{Predictors of meat consumption among consumers} who reported eating little or no meat

Self-declared low-meat consumers varied considerably in their meat intake levels (Tables 2 and 3). A three-step hierarchical regression analysis was conducted to identify factors associated with higher total meat intake in these participants (Table 5). The correlations between the predictors and total meat consumption are shown in Appendix 2. The final regression model including all variables was significant with $F_{(17,1595)}=23 \cdot 16, P<0.001$ and explained about $20 \%$ of the variance. Motives alone accounted for $11 \%$ of the variance in total meat consumption (model 2); the sociodemographic variables (model 1) and consumption of plant-based meat alternatives with the perceived difficulty of practising a low/no-meat diet (model 3) explained an additional $4 \%$ and $5 \%$, respectively.

Female gender was a significant predictor of lower total meat consumption in models 1 and 2 (see Table 5) but no longer significant when the perceived difficulty of practising a low/no-meat diet and plant-based protein consumption were additionally included in model 3; age and income did not predict meat consumption. Stronger motives regarding animal welfare and a stronger preference for vegetarian foods were associated with lower meat consumption, and stronger weight-loss motivation was associated with higher meat consumption. All the other motives included were not significant predictors. Participants who perceived following a low-meat or meatless diet as more difficult consumed more meat. None of 
Table 5 Hierarchical multiple regression analysis predicting total meat consumption in a sample of Swiss adults who reported eating little or no meat ( $n$ 1596); Swiss Food Panel 2.0 (survey 2017)

\begin{tabular}{|c|c|c|c|c|c|c|c|c|c|}
\hline \multirow[b]{2}{*}{ Predictors } & \multicolumn{3}{|c|}{ Model 1} & \multicolumn{3}{|c|}{ Model 2} & \multicolumn{3}{|c|}{ Model 3} \\
\hline & $B$ & SE $B$ & $99 \% \mathrm{Cl}$ & $\mathrm{B}$ & SE $B$ & $99 \% \mathrm{Cl}$ & $B$ & SE $B$ & $99 \% \mathrm{Cl}$ \\
\hline Constant & $5 \cdot 36^{\star \star *}$ & 0.56 & $4.02,6 \cdot 89$ & $7 \cdot 33^{\star \star *}$ & 0.63 & $5.73,9.00$ & $5 \cdot 44^{\star * \star}$ & 0.65 & $3 \cdot 92,7 \cdot 12$ \\
\hline Gender & $-1.66^{\star \star \star}$ & 0.23 & $-2.23,-1.09$ & $-0 \cdot 70^{\star \star}$ & 0.22 & $-1 \cdot 30,-0.11$ & -0.52 & 0.22 & $-1.08,0.10$ \\
\hline Age & 0.01 & 0.01 & $-0.01,0.03$ & 0.01 & 0.01 & $-0.01,0.02$ & 0.01 & 0.01 & $-0.01,0.03$ \\
\hline Income & 0.05 & 0.07 & $-0.13,0.24$ & 0.09 & 0.07 & $-0.08,0.27$ & 0.08 & 0.06 & $-0.07,0.25$ \\
\hline Animal welfare & & & & $-0.37^{\star \star \star}$ & 0.06 & $-0.54,-0.20$ & $-0.39^{\star \star \star}$ & 0.07 & $-0.56,-0.20$ \\
\hline Environmental concerns & & & & -0.10 & 0.06 & $-0.26,0.05$ & -0.13 & 0.06 & $-0.29,0.03$ \\
\hline Weight regulation & & & & $0.26^{\star \star}$ & 0.07 & $0.08,0.43$ & $0.20^{* *}$ & 0.07 & $0.01,0.38$ \\
\hline Health/healthy diet & & & & -0.04 & 0.05 & $-0.18,0.09$ & -0.04 & 0.05 & $-0.18,0.09$ \\
\hline Medical advice & & & & 0.19 & 0.10 & $-0.04,0.43$ & 0.13 & 0.09 & $-0.09,0.35$ \\
\hline Disliking the taste of meat & & & & -0.05 & 0.06 & $-0.20,0.10$ & -0.001 & 0.05 & $-0.14,0.15$ \\
\hline Preferring vegetarian dishes & & & & $-0.32^{\star \star *}$ & 0.05 & $-0.47,-0.19$ & $-0 \cdot 28^{\star \star \star}$ & 0.06 & $-0.42,-0.12$ \\
\hline Religious rules & & & & -0.20 & 0.13 & $-0.53,0.19$ & -0.20 & 0.12 & $-0.51,0.10$ \\
\hline Been brought up that way & & & & 0.04 & 0.06 & $-0.11,0.18$ & 0.10 & 0.06 & $-0.06,0.24$ \\
\hline Social expectations & & & & 0.24 & 0.11 & $-0.05,0.53$ & 0.13 & 0.11 & $-0.18,0.38$ \\
\hline Perceived difficulty & & & & & & & $0.64^{\star * \star}$ & 0.09 & $0.41,0.84$ \\
\hline Meat substitutes & & & & & & & 0.02 & 0.24 & $-0.54,0.31$ \\
\hline Soya products & & & & & & & 0.05 & 0.08 & $-0.15,0.20$ \\
\hline Legumes & & & & & & & 0.13 & 0.06 & $-0.02,0.30$ \\
\hline
\end{tabular}

$B$, unstandardised beta; SE $B$, standard error of $B$; $99 \% \mathrm{Cl}, 99 \%$ bias-corrected accelerated $\mathrm{Cl}$ (predictors are significant if the $99 \% \mathrm{Cl}$ of $B$ does not include 0 ).

Results are based on 1000 bootstrap samples.

Total $R^{2}=0.20, R^{2}=0.04$ for step $1, \Delta R^{2}=0.11$ for step $2, \Delta R^{2}=0.05$ for step 3 .

Gender: $1=$ female, $0=$ male.

${ }^{* \star} P<0.01,{ }^{* \star *} P \leq 0.001$.

the plant-based alternative sources of protein were associated with lower meat intake.

\section{Discussion}

The motives for pursuing a vegetarian or semi-vegetarian diet are diverse. The present study assessed the prevalence of commonly mentioned motives for following a vegetarian diet among a large sample of self-declared low-meat consumers as well as vegetarians/vegans and pescatarians. Our study confirmed the finding that most individuals are motivated by more than one reason but that certain motives differ in importance depending on the diet style with which people identify ${ }^{(22,24)}$. Although vegetarians and pescatarians indicated largely similar motives for their dietary choices regarding meat, compared with low-meat consumers these two groups are more strongly driven by concerns about animal welfare and environmental issues associated with meat consumption, as well as by taste preferences. Regarding health motives, no differences were observed between vegetarians and non-vegetarians in the motivation to eat healthily, but weight loss turned out to be a stronger motivation in female low-meat consumers than in female vegetarians. Previous studies have reported similar motivational differences regarding weight regulation, especially in young women ${ }^{(24,32)}$. However, the absolute values in our sample (see Fig. 1) indicate that the weight-loss motivation was much less prevalent across all the diet groups than was the motivation to eat healthily. A possible explanation for why the groups did not differ regarding their motivation to eat healthily is that beliefs about the healthiness of meat vary among consumers, some of whom associate it with negative health outcomes and some of whom perceive meat as an important source of essential nutrients such as protein and iron, and therefore as a component of a healthy diet ${ }^{(33)}$. In a recent Belgian study, only about $22 \%$ of the respondents believed that meat consumption is unhealthy ${ }^{(23)}$. Moreover, about $24 \%$ even viewed eating vegetarian food frequently as unhealthy ${ }^{(23)}$. As suggested by previous research, consumers' awareness of the environmental impact of meat consumption is generally rather low ${ }^{(34)}$ and they tend to underestimate it compared with other product characteristics, such as the packaging ${ }^{(35)}$. Because both the vegetarians and semi-vegetarians in our study reported a relatively high environmental motivation for their dietary choices regarding meat, we suggest that people practising these diet styles are more aware of and knowledgeable about the environmental issues associated with meat production than are regular meat consumers. However, this inference requires further exploration.

Similarly to earlier studies ${ }^{(18,36,37)}$, we observed an inconsistency between people's self-declaration as vegetarian and their self-reported meat consumption in the sFFQ. On average, vegetarians and pescatarians reported consuming meat occasionally or even regularly. There are several possible explanations for this discrepancy. Although there are many vegetarian and vegan alternatives to meat ${ }^{(17)}$ vegetarians may still face situations in which these foods are unavailable, leaving them no meat-free options $^{(18)}$. Furthermore, in certain social situations occasional meat intake may be necessary to avoid embarrassment ${ }^{(18)}$. Interestingly, in our study the meat consumption of vegetarian males was considerably higher than that 
of vegetarian females. Apart from males' generally higher food intake ${ }^{(38)}$, a possible explanation for this finding is that males face more social pressure to eat meat in certain situations. Moreover, meat is often associated with typical masculine attributes (e.g. power and virility ${ }^{(39)}$ ) and vegetarian men are perceived as weaker and less masculine compared with omnivores ${ }^{(39)}$, especially by other men. This may also explain why males perceived it as more difficult to consistently follow a vegetarian diet in our sample. Nevertheless, even though the questionnaire in the present study explicitly defined the diet styles, the self-evaluation of diet style seems to be problematic. People may have different ideas of what constitutes a vegetarian diet and the social consensus regarding the definition of such a diet may not always be sufficiently clear ${ }^{(36)}$. Moreover, self-identified vegetarians may differ in how strictly they follow their diet, to what degree they allow themselves to make exceptions, and how strongly they experience cognitive dissonance or inner conflict when consuming meat.

Apparently, although a substantial number of meat eaters view their meat intake as rather low, this is not in fact the case when comparing their consumption level with official dietary recommendations. In our sample, about $81 \%$ of the male and $69 \%$ of the female self-declared low-meat consumers exceeded the recommended upper limit of three portions per week $^{(15)}$. This finding has implications for the efforts of public health organisations to bring peoples' meat consumption within a healthy range. It demonstrates the need for further awareness campaigns to disseminate appropriate knowledge about the dietary recommendations for meat and to enable an accurate self-evaluation of one's meat intake.

Our analyses support the assumption that both vegetarian and semi-vegetarian diets are beneficial for health ${ }^{(11,40)}$, contributing to a better diet quality and to a healthy body weight. However, for obese males, these associations were not shown in our sample. Based on our results, vegetarians and pescatarians seemed not to compensate for the absence of meat in their diets by eating more other animal-based proteins such as eggs or dairy products. And for plant-based proteins, gender differences seem to exist. Whereas vegetarian women reported higher intake of all kinds of plant-based proteins, vegetarian males hardly differed from their omnivore counterparts in this respect. Moreover, among low/no-meat consumers, higher consumption frequencies of plant-based protein sources were not associated with lower meat intake, which may indicate that the available products are not perceived as equivalent alternatives for meat. Nevertheless, regular and low-meat eaters also seem to consume meat substitutes on occasion. The low consumption frequencies reported, however, suggest that the products currently on the market may not be sufficiently satisfying, especially for avid meat eaters. Hence, these omnivores may represent an interesting market segment, especially considering their size and the potential market share of total consumption. Therefore, industries should focus their efforts on using new food technologies to improve the taste and texture of meat substitutes in order to increase their similarity to real meat. This may help to convince omnivores that such products are viable alternatives to meat and may encourage them to replace meat with plant-based protein sources more often. However, our results equally suggest that different target groups in the food market have opposite needs from meat substitutes. On the one hand, there is a large group of omnivores with a low willingness to give up meat consumption, creating a need for meat substitutes that are very similar to meat. On the other hand, as we have seen, many vegetarians do not like the taste of meat or prefer vegetarian options, creating a need for meat alternatives that do not taste like meat but have the same functionality.

\section{Strengths and limitations}

The large sample size of randomly selected participants and the equal inclusion of males and females represent clear strengths of our study. However, there are also some limitations that should be mentioned. The first is related to the assessment of BMI. Self-reported body weight can be subject to under-reporting, especially in women and heavier individuals ${ }^{(41)}$, and thus might lead to less accurate estimations of weight status. However, the use of BMI based on self-reported data is very common in large nutritional studies and direct measurements would not be feasible. Moreover, it has been shown that the correlation between self-reported and objectively measured weight is relatively high ${ }^{(42)}$. Another limitation is the way we asked participants whether or not they viewed their usual meat consumption as low. Future studies should provide a clearer definition of what is understood under a low consumption. Otherwise, participants' understanding of low consumption will remain unclear as will the standard to which it is related, such as official dietary recommendations, the consumption level of friends and relatives, or a participant's own consumption at an earlier time. We also did not assess consumers' familiarity with the official dietary recommendations for meat, which is relevant.

\section{Conclusion and implications for public health}

The present study supports the assumption that ethical motives along with taste preferences are more prevalent in consumers identifying with a vegetarian lifestyle, whereas weight-loss motivation plays a more important role for lowmeat consumers, especially in women. It also contributes new evidence that vegetarian and semi-vegetarian diets may be associated with better diet quality and a lower prevalence of overweight, even though these associations should be further investigated in long-term studies. Further, the study reveals that a substantial number of consumers view their meat consumption as low even though this is not the case when comparing their intake levels with the 
official dietary recommendations. This has implications for public health organisations' efforts to promote healthy levels of meat consumption in the public. Our study provides some hints for where to start. First, there seems to be a lack of knowledge about what is considered a low meat intake. Many people seem to have incorrect reference standards. This problem could be addressed with public awareness campaigns in order to improve consumers' knowledge about and ability to appropriately evaluate their own meat intake. Second, our results suggest that the perceived difficulties of practising a diet with little or no meat were associated with higher meat consumption and thus constitute a barrier to reaching a healthy meat-intake level. This highlights the need for public health programmes which provide strategies to support people in eating more plantbased diets and to break their 'bad' habits regarding meat. Enhancing the familiarity with and preference for vegetarian alternatives, for example by launching campaigns for meatless days (e.g. 'veggie day'(23,43) , implementing campaigns for portion size reduction ${ }^{(43)}$ or addressing concerns about animal welfare may be effective ways to promote healthier and more sustainable diets in the public without suggesting that consumers must completely stop meat consumption.

\section{Acknowledgements}

Financial support: This research received no specific grant from any funding agency in the public, commercial or not-for-profit sectors. Conflict of interest: The authors declared no conflict of interest. Authorship: M.S. and C.H. participated in the design of the study; D.H. and C.H. conducted the data analysis; D.H. wrote the manuscript; M.S. and C.H. made critical comments on the draft. Ethics of buman subject participation: This study was conducted according to the guidelines laid down in the Declaration of Helsinki and all procedures involving human subjects were approved by the Ethics Committee of ETH Zurich (EK 2017-N-19). Written informed consent was obtained from all subjects.

\section{References}

1. Burkholder N, Rajaram S \& Sabaté J (2016) Vegetarian diets. In Encyclopedia of Food and Health, pp. 401-410 [B Caballero, PM Finglas and F Toldrá, editors]. Cambridge, MA: Academic Press/Elsevier.

2. Aiking H (2011) Future protein supply. Trends Food Sci Technol 22, 112-120.

3. Tukker A, Goldbohm RA, de Koning A et al. (2011) Environmental impacts of changes to healthier diets in Europe. Ecol Econ 70, 1776-1788.

4. Westhoek H, Lesschen JP, Rood T et al. (2014) Food choices, health and environment: effects of cutting Europe's meat and dairy intake. Global Environ Change 26, 196-205.
5. Battaglia Richi E, Baumer B, Conrad B et al. (2015) Health risks associated with meat consumption: a review of epidemiological studies. Int J Vitam Nutr Res 85, 70-78.

6. Hever J \& Cronise RJ (2017) Plant-based nutrition for healthcare professionals: implementing diet as a primary modality in the prevention and treatment of chronic disease.J Geriatr Cardiol 14, 355-368.

7. Appleby P, Thorogood JI \& Key TJ (1998) Low body mass index in non-meat eaters: the possible roles of animal fat, dietary fibre and alcohol. Int $J$ Obes Relat Metab Disord 22, 454-460.

8. de Jonge J, van der Lans IA \& van Trijp HCM (2015) Different shades of grey: compromise products to encourage animal friendly consumption. Food Qual Prefer 45, 87-99.

9. Rothgerber H (2015) Can you have your meat and eat it too? Conscientious omnivores, vegetarians, and adherence to diet. Appetite 84, 196-203.

10. Swissveg (2017) Veggie survey 2017. https://www.swissveg. ch/veggie_survey?language=en (accessed July 2018).

11. Derbyshire EJ (2016) Flexitarian diets and health: a review of the evidence-based literature. Front Nutr 3, 55.

12. Pollan M (2006) The Omnivore's Dilemma. The Search for a Perfect Meal in a Fast-Food World. London: Bloomsbury.

13. Food and Agriculture Organization of the United Nations (2018) Food Balance Sheets. http://www.fao.org/faostat/en/\#data/ FBS (accessed July 2018).

14. Henchion M, McCarthy M, Resconi VC et al. (2014) Meat consumption: trends and quality matters. Meat Sci $\mathbf{9 8}, 561-568$.

15. Swiss Society for Nutrition (2017) Schweizer Lebensmittelpyramide (Swiss food pyramid). http://www.sge-ssn.ch/ich-und-du/ essen-und-trinken/ausgewogen/schweizer-lebensmittelpyramide (accessed November 2017).

16. World Cancer Research Fund International \& American Institute for Cancer Research (2018) Continuous Update Project Expert Report 2018. Recommendations and public health and policy implications. https://www.wcrf.org/sites/ default/files/Cancer-Prevention-Recommendations-2018.pdf (accessed November 2018).

17. Apostolidis C \& McLeay F (2016) Should we stop meating like this? Reducing meat consumption through substitution. Food Policy 65, 74-89.

18. Ruby MB (2012) Vegetarianism. A blossoming field of study. Appetite 58, 141-150.

19. Organisation for Economic Co-operation and Development (2019) Meat consumption (indicator). Publication no. 10.1787/fa290fd0-en. https://data.oecd.org/agroutput/meatconsumption.htm (accessed January 2019).

20. Rees JH, Bamberg S, Jäger A et al. (2018) Breaking the habit: on the highly habitualized nature of meat consumption and implementation intentions as one effective way of reducing it. Basic Appl Soc Psychol 40, 136-147.

21. Ruby MB, Heine SJ, Kamble S et al. (2013) Compassion and contamination. Cultural differences in vegetarianism. Appetite 71, 340-348.

22. De Backer CJ \& Hudders L (2014) From meatless Mondays to meatless Sundays: motivations for meat reduction among vegetarians and semi-vegetarians who mildly or significantly reduce their meat intake. Ecol Food Nutr 53, 639-657.

23. Mullee A, Vermeire L, Vanaelst B et al. (2017) Vegetarianism and meat consumption: a comparison of attitudes and beliefs between vegetarian, semi-vegetarian, and omnivorous subjects in Belgium. Appetite 114, 299-305.

24. Forestell CA, Spaeth AM \& Kane SA (2012) To eat or not to eat red meat. A closer look at the relationship between restrained eating and vegetarianism in college females. Appetite $\mathbf{5 8}$, 319-325.

25. de Boer J, Schosler H \& Aiking H (2017) Towards a reduced meat diet: mindset and motivation of young vegetarians, low, medium and high meat-eaters. Appetite 113, 387-397. 
26. Hu FB, Satija A, Rimm EB et al. (2016) Diet assessment methods in the Nurses' Health Studies and contribution to evidence-based nutritional policies and guidelines. Am J Public Health 106, 1567-1572.

27. Malik VS, Willett WC \& Hu FB (2013) Global obesity: trends, risk factors and policy implications. Nat Rev Endocrinol 9 , 13-27.

28. Lassale C, Gunter MJ, Romaguera D et al. (2016) Diet quality scores and prediction of all-cause, cardiovascular and cancer mortality in a pan-European cohort study. PLoS One 11, e0159025.

29. McNaughton SA, Ball K, Crawford D et al. (2008) An index of diet and eating patterns is a valid measure of diet quality in an Australian population. J Nutr 138, 86-93.

30. Swiss Federal Statistical Office (2012) Schweizerische Gesundheitsbefragung (SGB) (Swiss Health Survey (SHS)). Neuchâtel, Switzerland: BFS Bundesamt für Statistik.

31. Field A (2013) Discovering Statistics using IBM SPSS Statistics, 4th ed. London: SAGE.

32. Gilbody SM, Kirk SF \& Hill AJ (1999) Vegetarianism in young women: another means of weight control? Int J Eat Disord 26, 87-90.

33. Verbeke W, Perez-Cueto FJ, Barcellos MD et al. (2010) European citizen and consumer attitudes and preferences regarding beef and pork. Meat Sci 84, 284-292.

34. Hartmann C \& Siegrist M (2017) Consumer perception and behaviour regarding sustainable protein consumption: a systematic review. Trends Food Sci Technol 61, 11-25.

\section{Appendix 1}

Foods and beverages included in the diet quality index
35. Tobler C, Visschers VH \& Siegrist M (2011) Eating green. Consumers' willingness to adopt ecological food consumption behaviors. Appetite 57, 674-682.

36. Rothgerber H (2014) A comparison of attitudes toward meat and animals among strict and semi-vegetarians. Appetite $\mathbf{7 2}$, 98-105.

37. Vinnari M, Montonen J, Harkanen T et al. (2009) Identifying vegetarians and their food consumption according to selfidentification and operationalized definition in Finland. Public Health Nutr 12, 481-488.

38. Herman CP \& Polivy J (2010) Sex and gender differences in eating behavior. In Handbook of Gender Research in Psychology, vol. 1, pp. 455-469 [J Chrisler and D McCreary, editors]. New York: Springer.

39. Ruby MB \& Heine SJ (2011) Meat, morals, and masculinity. Appetite 56, 447-450.

40. McEvoy CT, Temple N \& Woodside JV (2012) Vegetarian diets, low-meat diets and health: a review. Public Health Nutr 15, 2287-2294.

41. Gunnare NA, Silliman K \& Morris MN (2013) Accuracy of selfreported weight and role of gender, body mass index, weight satisfaction, weighing behavior, and physical activity among rural college students. Body Image 10, 406-410.

42. Luo J, Thomson CA, Hendryx M et al. (2019) Accuracy of selfreported weight in the Women's Health Initiative. Public Health Nutr 22, 1019-1028.

43. de Boer J, Schösler H \& Aiking H (2014) 'Meatless days' or 'less but better'? Exploring strategies to adapt Western meat consumption to health and sustainability challenges. Appetite 76, 120-128.

\begin{tabular}{|c|c|c|c|}
\hline Food group & $\begin{array}{l}\text { Official dietary recommendation of the } \\
\text { Swiss Society for Nutrition }\end{array}$ & Scoring & $\begin{array}{l}\text { Percentage of participants in the } \\
\text { Swiss Food Panel } 2.0 \text { study meeting } \\
\text { the recommendations }\end{array}$ \\
\hline Fruits & Minimum 2 per day (= 14 per week) & $\begin{array}{l}\geq 14 \text { portions } / \text { week }=1 \\
<14 \text { portions } / \text { week }=0\end{array}$ & $32 \cdot 6$ \\
\hline Vegetables and salad & Minimum 3 per day (= 21 week) & $\begin{array}{l}\geq 21 \text { portions } / \text { week }=1 \\
<21 \text { portions } / \text { week }=0\end{array}$ & 23.5 \\
\hline Wholegrain products & $\begin{array}{l}\text { Should be preferred compared with } \\
\text { refined-grain products (no specific portion } \\
\text { recommendation) }\end{array}$ & $\begin{array}{l}\geq 1 \text { portion } / \text { week }=1 \\
<1 \text { portion } / \text { week }=0\end{array}$ & $82 \cdot 8$ \\
\hline Meat and meat products & Maximum 2-3 portions per week & $\begin{array}{l}\leq 3 \text { portions } / \text { week }=1 \\
>3 \text { portions } / \text { week }=0\end{array}$ & $18 \cdot 0$ \\
\hline $\begin{array}{l}\text { Sweets, salty snacks, } \\
\text { sugar-sweetened } \\
\text { beverages, alcohol }\end{array}$ & $\begin{array}{l}\text { With moderation; a small portion of sweets } \\
\text { or salty snacks or sugar-sweetened } \\
\text { beverage or alcohol per day } \\
\text { (= } 7 \text { per week) }\end{array}$ & $\begin{array}{l}\leq 7 \text { portions } / \text { week }=1 \\
>7 \text { portions } / \text { week }=0\end{array}$ & $22 \cdot 2$ \\
\hline
\end{tabular}


Appendix 2

Correlations of total meat consumption and predictors. Calculations based on the sub-sample of participants who reported eating little or no meat (n 1596); Swiss Food Panel 2.0 (survey 2017)

\begin{tabular}{|c|c|c|c|c|c|c|c|c|c|c|c|c|c|c|c|c|c|}
\hline & Variable & 1 & 2 & 3 & 4 & 5 & 6 & 7 & 8 & 9 & 10 & 11 & 12 & 13 & 14 & 15 & 16 \\
\hline 1 & Age & - & & & & & & & & & & & & & & & \\
\hline 2 & Income & $-0.20^{* * *}$ & - & & & & & & & & & & & & & & \\
\hline 3 & Animal welfare & NS & NS & - & & & & & & & & & & & & & \\
\hline 4 & $\begin{array}{l}\text { Environmental } \\
\text { concerns }\end{array}$ & $-0.09^{\star \star *}$ & NS & $0.55^{\star \star \star}$ & - & & & & & & & & & & & & \\
\hline 5 & $\begin{array}{l}\text { Weight } \\
\text { regulation }\end{array}$ & $0.14^{\star \star \star}$ & $-0.07^{\star \star}$ & $-0.09^{\star \star \star}$ & $-0.07^{\star \star}$ & - & & & & & & & & & & & \\
\hline 6 & $\begin{array}{l}\text { Health/ } \\
\text { healthy diet }\end{array}$ & $0.14^{\star \star \star}$ & NS & $0.20^{* \star *}$ & $0.25^{\star \star \star}$ & $0.25^{\star \star \star}$ & - & & & & & & & & & & \\
\hline 7 & Medical advice & $0.15^{\star \star \star}$ & $-0.08^{* *}$ & NS & NS & $0.28^{\star \star \star}$ & $0 \cdot 10^{\star \star \star}$ & - & & & & & & & & & \\
\hline 8 & $\begin{array}{l}\text { Disliking } \\
\text { the taste } \\
\text { of meat }\end{array}$ & NS & NS & $0 \cdot 15^{\star \star \star}$ & NS & NS & NS & NS & - & & & & & & & & \\
\hline 9 & $\begin{array}{l}\text { Preferring } \\
\text { vegetarian } \\
\text { dishes }\end{array}$ & NS & NS & $0.27^{\star \star \star}$ & $0.17^{\star \star \star}$ & NS & $0.14^{\star \star *}$ & NS & $0.51^{* * *}$ & - & & & & & & & \\
\hline 10 & $\begin{array}{l}\text { Religious } \\
\text { rules }\end{array}$ & NS & $-0.08^{\star \star}$ & NS & NS & $0.09^{* * *}$ & NS & $0 \cdot 13^{\star \star \star}$ & $0.08^{* *}$ & $0.08^{\star \star}$ & - & & & & & & \\
\hline 11 & $\begin{array}{l}\text { Been } \\
\text { brought up } \\
\text { that way }\end{array}$ & NS & $-0.07^{\star \star}$ & NS & $0.09^{\star \star \star}$ & $0 \cdot 14^{\star \star \star}$ & $0.07^{* *}$ & $0 \cdot 13^{\star \star \star}$ & $0.07^{* *}$ & NS & $0 \cdot 20^{\star \star \star}$ & - & & & & & \\
\hline 12 & $\begin{array}{l}\text { Social } \\
\quad \text { expectations }\end{array}$ & $0.11^{\star \star *}$ & NS & NS & $0.14^{* * *}$ & $0 \cdot 17^{\star \star \star}$ & NS & $0.22^{\star \star \star}$ & NS & NS & $0.28^{\star \star \star}$ & $0.42^{\star \star \star}$ & - & & & & \\
\hline 13 & $\begin{array}{l}\text { Perceived } \\
\text { difficulty } \dagger\end{array}$ & NS & NS & NS & NS & $0.14^{\star \star \star}$ & NS & $0 \cdot 10^{\star \star \star}$ & $-0 \cdot 20^{\star \star \star}$ & $-0 \cdot 21^{\star \star \star}$ & NS & NS & $0 \cdot 14^{\star \star *}$ & - & & & \\
\hline 14 & $\begin{array}{l}\text { Meat } \\
\text { substitutes } \\
\text { consumption } \neq\end{array}$ & $-0 \cdot 17^{\star \star \star}$ & NS & $0.20^{\star \star \star}$ & $0.15^{\star \star \star}$ & NS & NS & NS & NS & $0 \cdot 15^{\star \star \star}$ & NS & NS & NS & $-0 \cdot 10^{\star \star \star}$ & - & & \\
\hline 15 & $\begin{array}{l}\text { Soya products } \\
\text { consumption }\end{array}$ & $-0.11^{\star \star *}$ & NS & $0.12^{\star \star \star}$ & $0 \cdot 10^{\star \star \star}$ & NS & $0.09^{* \star *}$ & NS & NS & $0.08^{\star \star \star}$ & NS & NS & NS & NS & $0.52^{\star \star \star}$ & - & \\
\hline 16 & $\begin{array}{l}\text { Legumes } \\
\text { consumption }\end{array}$ & $-0 \cdot 10^{\star \star \star}$ & NS & $0.12^{\star \star \star}$ & $0.11^{\star \star \star}$ & $0.06^{\star *}$ & $0 \cdot 10^{* \star *}$ & NS & NS & NS & NS & NS & NS & NS & $0.29^{\star \star \star}$ & $0.21^{* \star *}$ & - \\
\hline 17 & $\begin{array}{l}\text { Total meat } \\
\text { consumption }\end{array}$ & $0.06^{\star *}$ & NS & $-0.26^{\star * *}$ & $-0 \cdot 16^{\star * *}$ & $0 \cdot 16^{\star \star \star}$ & NS & $0 \cdot 12^{\star \star \star}$ & $-0 \cdot 15^{\star \star \star}$ & $-0.24^{* * *}$ & NS & NS & $0.09^{\star \star \star}$ & $0.26^{\star \star \star}$ & NS & NS & NS \\
\hline
\end{tabular}

$n$ vary due to missing values.

${ }^{* *} P<0.01$ (two-tailed), ${ }^{* \star *} P \leq 0.001$ (two-tailed).

†Perceived difficulty of practising a diet with little or no meat.

fIncluding meat substitutes such as tofu, Quorn, seitan, and vegetarian cold cuts (in portions per week). 